\title{
Appointing a President that Represents the Unity of The People in Kosovo
}

\author{
Florent Muçaj \& Avdylkader Mucaj \\ Faculty of Law, University of Prishtina "Hasan Prishtina”, Kosovo \\ Faculty of Law, University of Prizren "Ukshin Hoti", Kosovo \\ florent.muqaj@uni-pr.edu; mucajavdylkader@gmail.com
}

MUÇAJ, Florent; Mucaj, Avdylkader. Appointing a President that Represents the Unity of the People in Kosovo. International and Comparative Law Review, 2017, vol. 17, no. 1, pp. 193-210. DOI 10.2478/iclr-2018-0008.

\begin{abstract}
Summary: The article examines the constitutional position of the president of republic in the view of the appointment procedure established in Hamiti et al and Derguti et al. Both constitutional court decisions have construed a rhetorical interpretation of the expected role of the president of republic as representative of the unity of the people in a constitutional nutshell. The article questions both decisions' structural rationality and legitimacy in what is likely a tough political controversy requiring two-third majority for the appointment of the president of republic in the first two rounds. To better designate the logic upon which the court relied when ruling in the two decisions, the article considers relevant comparative literature and case-law to channel the analysis. The article concludes that though the court demonstrated a rather activist tone in interpreting the procedure for the appointment of the president of republic, it also showed quite unprecedented willingness to constitutionally empower the position of the president of republic on basis of appointment-related preconditions.
\end{abstract}

Keywords: The President, the Unity of People Concept, Constitutional Court, Constitutional Provisions, Presidential Election Procedures, the Quorum.

\section{Introduction}

Although the Constitution of the Republic of Kosovo is less than a decade old, Kosovo's Constitutional Court has already engaged actively on several issues relating to the model of governance and to the interaction of institutions vis-a$v i s$ the principle of separation of powers. Of the core political institutions regulated specifically by the constitution, the presidency - more specifically, the scope, nature and authority of the president as the head of state of the Republic - has often come under review by the Constitutional Court. Several decisions of the court have not only attracted significant scholarly attention but have also provoked numerous debates relating to the values and authority of a head of state in a parliamentary democracy. A popular point of contention has been, and remains, the nature and scope of the president's role as a 'representative of the 
unity of the people'. Although this concept is neither new nor unseen in the developed world, ${ }^{2}$ for Kosovo resulted to be very challenging regarding representing the unity of the people by the President. The views of the Constitutional Court concerning the unity of people in the above mentioned cases were directly reflective in the new democracy in Kosovo, institutional separation of powers as well as next procedural appointment of the President ${ }^{3}$.

The unity of the people is one of the most difficult concepts to define in constitutional theory. This is due to the fact that neither constitutional theory nor constitutional practice gives a precise definition of what it means in tangible terms, although the concept has been mentioned in different constitutions. Debates on the unity of the people as constitutional concept has gained special importance in the last century, especially after the arguments and counter arguments of the theorists of law such as Hans Kelzen and Carl Schmitt had seen great attention. While Kelzen considered unity of the people only as a normative legal issue, ${ }^{4}$ Schmitt saw it in a broader context, giving greater importance to

1 The Constitution of the Republic of Kosovo in force, in Article 83 states that the President of the Republic of Kosovo, among others represents the unity of the people.

2 See: CONSTITUTION of Bulgaria [1991, rev.2015], Article 92.1; FRENCH Constitution [1958, rev.2008]; Article CONSTITUTION of Italy [1947, rev.2012], Article 87; CONSTITUTION of the Kingdom of Spain [1978, rev.2012], Article 56; CONSTITUTION of Rumania [1991, rev.2003], Article 80.1; CONSTITUTION of Croatia [1991, rev.2010] Article 94; CONSTITUTION of Iraq [2005] Article 67; CONSTITUTION of Kenya [2010] Article 131.1.e; CONSTITUTION of Serbia [2006] Article 111; CONSTITUTION of Turkey [1982, rev.2011] Article 104; CONSTITUTION of Portugal [1982, rev.2005] Article 120; CONSTITUTION of Pakistan [1973, rev.2015] Article 41.1.; CONSTITUTION of Albania [1998, rev.2012], Article 86.1. etc. However, Constitutions of different countries do not mention the unity of people as an attribute of the President such as: CONSTITUTION of Armenia [1995, rev.2005]; CONSTITUTION of Australia [1945, rev.2013]; CONSTITUTION of Belgium [1831, rev.2014]; CONSTITUTION of Switzerland [1999, rev.2014]; CONSTITUTION of Canada [1867, rev.2011]; CONSTITUTION of Chile [1980, rev.2015]; CONSTITUTION of Costa Rica [1949, rev.2011]; CONSTITUTION of Cyprus [1960, rev.2013]; CONSTITUTION of Czech Republic [1993, rev.2013]; CONSTITUTION of Denmark [1953]; CONSTITUTION of Bosnia and Herzegovina [1995, rev.2009]; CONSTITUTION of Slovenia [1991]; and CONSTITUTION of Germany [1949, rev.2014]. etc. [Online]. Available at: https://www.constituteproject.org/search?lang=en. Accessed: 2 April 2017.

3 Except cases that are mentioned in this article from the Constitutional Court of Kosovo, this court has discussed the role of the president in other cases, e.g. see: Judgment Case No. KI47/10 Prishtina, 28 September 2010 Ref. no: AGJ 43/110 "Naim Rrustemi and 31 other Deputies of the Assembly of the Republic of Kosovo", Vs. His Excellency, Fatmir Sejdiu, President of the Republic of Kosovo, 28 September 2010. [Online]. Available at: http:// www.gjk-ks.org/repository/docs/ki_47_10_eng_1.pdf., and JUDGMENT in Cases K.O. 29/12 and K.O. 48/12 "Proposed Amendments of the Constitution submitted by the President of the Assembly of the Republic of Kosovo" on 23 March 2012 and 4 May 2012, 20 July 2012. [Online]. Available at: http://www.gjk-ks.org/repository/docs/Aktgjykim\%20 Anex\%20A\&B\%20KO29_48_12_ANG.pdf. Accessed: 30.03.2017.

4 CORRIAS, Luigi. The Passivity of Law - Competence and Constitution in the European 
the sociological as well as the political dimension. He argued that only the President is the one who represents the unity of the people. However, the role of the president as a 'representative of the unity of the people' has been debated in some Kosovo's constitutional cases, and, generally speaking, it has been invoked mainly during procedures to appoint the president.

Therefore, this paper examines the concept of the president as 'representative of the unity of the people' in its application during presidential appointment procedures ${ }^{6}$. Moreover, it generally reflects the views and interpretations featured in two landmark decisions, namely Hamiti et al $(2011)^{7}$ and Derguti et al (2016) $)^{8}$. In both cases, the court reviewed several contexts on which the concept of the president as 'representative of the unity of the people' could be applied. As a result, the court designed and established some standards to guide the application of this principle in the future.

\section{The context out of which the two constitutional controversies arose}

After the Republic of Kosovo declared its independence in February $2008^{9}$. it adopted a new Constitution on April 9, 2008 which came into effect on June $15,2008^{10}$. The Constitution established a parliamentary system, ${ }^{11}$ with a presi-

Court of Justice. London, Springer, 2011, pp.49-50.

5 COUTINHO, Luis, Pereira, LA TORRE, SMITH, D. Steven. Judicial Activism - An Interdisciplinary Approach to the American and European Experience. Ius Gentium: Comparative Perspectives on Law and Justice 44, Springer International Publishing, Switzerland, 2014, pp.89.

6 The same principle seems applicable even in president's authority as veto player in the legislative process. "..The right to return legislation serves essential constitutional functions. First, the President's authority to return constitutionally objectionable laws enables the President to have a share on the legislative process representing the unity of the people... See: MORINA,Visar. The Legislative Veto from the perspective of the Kosovo Constitution. Denning Law Journal, vol 26, 2014, pp.19-45.

7 CONSTITUTIONAL COURT OF THE REPUBUC OF KOSOVO, JUDGMENT in Case No. KO 29/11 Applicants Sabri Hamiti and other Deputies Pristina, Constitutional Review of the Decision of the Assembly of the Republic of Kosovo, No. 04-V-04, concerning the election of the President of the Republic of Kosovo, dated 22 February [2011]., 30 March 2011 Ref. No.: AGJ 107/11, paragraph 74. [Online]. Available at: http://www.gjk ks.org/ repository/docs/gjkk_ko_29_11_eng.pdf. Accessed: 10.03.2017

8 RESOLUTION in Inadmissibility of the Constitutional Court of Kosovo In Case No. K047/16 Applicants Aida Derguti, Bali Muharremaj, Enver Hoti and 25 other Deputies of the Assembly of the Republic of Kosovo Constitutional review of Decision No. 05-V-233, dated 26 February 2016, on the election of the President of the Republic of Kosovo [2016]. [Online]. Available at: http://www.gjk-ks.org/repository/docs/gjkk_ko_47_16_ang.pdf. Accessed: 10.03.2017

9 MARCO, Joseph. The New Kosovo Constitution in a Regional Comparative Perspective. Review of Central and East European Law 33, 2008, pp.437.

10 Judge TUNHEIM, John. Rule of Law and the Kosovo Constitution. Minnesota Journal Of Int'l Law, vol. 18:2, 2009, pp.373.

11 CONSTITUTION OF THE REPUBLIC OF KOSOVO. Article 4. This article explains the 
dent appointed by the Assembly ${ }^{12}$. In 2010, the issue of whether the president is constitutionally permitted to simultaneously hold the position of president and head of a political party arose before the Constitutional Court.

The court ruled that President Sejdiu committed a serious constitutional violation by holding both positions, leading to his resignation ${ }^{13}$. Because President Sejdiu was the head of the second coalition government party Democratic League of Kosovo (LDK), ${ }^{14}$ his resignation led to the breakup of the governing coalition. The parliament therefore passed a vote of no confidence, triggering early parliamentary elections. After the parliamentary elections in 2010, on February 22, 2011, the Assembly of the Republic of Kosovo carried out elections for Chairman of the Assembly and the President ${ }^{15}$.

The most pressing issues were still the formation of a coalition government and the appointment of a new president of the republic ${ }^{16}$. Two parties, the Democratic Party of Kosovo (PDK) and the New Kosovo Alliance (AKR) agreed to form a government directed by a PDK prime minister and to appoint the president nominated by $\mathrm{AKR}^{17}$. On February 22, 2011 the Assembly appointed, with an absolute majority of votes, Mr. Begjet Pacolli as the second president of the new republic ${ }^{18}$. Mr. Pacolli was the only candidate nominated for this post.

A large majority of the opposition MPs contested the appointment of Mr. Pacolli, ${ }^{19}$ alleging several constitutional procedural violations, one of them being the fact that more than one-third of opposition MPs had left the parliamentary session before Mr. Pacolli was voted in ${ }^{20}$ Only 67 out of the total of 120 MPs

principle of separation and control of powers and confirms that the Republic of Kosovo constitutionally operates according to the principles of a parliamentary system, 2008.

12 CONSTITUTION (note 11), Article 86.

13 The resignation of President Mr. Fatmir Sejdiu in 2010 came as a result of the Constitutional Court case no.KI47/10, Naim Rrustemi and others decided that President Fatmir Sejdiu violated the constitution, as he actively held the post of chairman of the political party, the Democratic League of Kosovo (LDK), contrary to rules stipulated in Article 88.2 of the Constitution of the Republic of Kosovo.

14 DEMOCRATIC LEAGUE OF KOSOVO.

15 MINUTES of the constitutive session of the Assembly of Kosovo, no.P001, February 22, 2011. [Online]. Available at: http://www.kuvendikosoves.org/common/docs/proc/ proc_s_2011_02_21_11_al.pdf. Accessed: 23.03.2017

16 CONSTITUTIONAL COURT, Case no.KI47/10 (note 3).

17 These parties were: the Democratic Party of Kosovo (PDK) and the Alliance for New Kosovo (AKR).

18 MINUTES of the meeting of the Assembly of the Republic of Kosovo, No. P-02, dated February 22, 2011.[Online]. Available at: http://www.kuvendikosoves. org/?cid=1,178\&date=2011-02. Accessed: 15.03.2017.

19 DEMOCRATIC INSTITUTE OF KOSOVO. Election of President by People: Necessity of time or common rhetoric. July, 2015.

20 According to the meeting minutes of the Assembly, dated February 22, 2011, no.-P-02, following the procedure of voting, the deputies of the political parties Democratic League of Kosovo (LDK), Alliance for the Future of Kosovo (AAK ) and political party Movement 
(more than half but far less than two-thirds of the members of the Assembly) were present for the vote. Art. 86 of the constitution establishes that there should be three rounds of voting in parliament for the appointment of the president of the republic, wherein the president is appointed in the first or second round with a two-thirds majority vote of all MPs or with a $50 \%+1$ majority in the third round of voting. A teleological reading of Art. 86 gives the understanding that the aim of such a procedure is to form cohesion among parties, resulting in the appointment of a president who has greater support than an absolute majority of MPs in parliament. In the three rounds of voting for the appointment of Mr. Pacolli to the post of President of the Republic, only 67 MPs were present and voted. ${ }^{21}$ Of those, only 62 voted in favor of his appointment (third round) and 4 voted against. One vote was declared invalid ${ }^{2223}$.

Shortly after the final vote to appoint the President, at the same meeting of the Assembly, ${ }^{24}$ he was sworn in and officially took office ${ }^{25}$. Opposition MPs looked for ways to contest the appointment of the President, and soon thereafter filed a claim with the Constitutional Court, alleging the unconstitutionality of the President's appointment. The resulting case of Hamiti et al is examined below.

\section{Hamiti et al before the court}

\subsection{Legal Basis of the claim}

The claim of Hamiti et al alleges that the decision of the Assembly to appoint Mr. Pacolli as the President of the Republic on 22 February 2011 violates Art. 86 of Kosovo's Constitution. The claim was submitted before the court by Mr. Hamiti and thirty-three other opposition members from the Assembly on 1 March 2011. The applicants contested the constitutionality of the Assembly's decision to appoint Mr. Pacolli, citing the procedure followed in the three plenary rounds of voting in the Assembly ${ }^{26}$. In essence, the claim questioned the appointment's compliance with Art. 86, especially paragraphs $4 \& 5$, which read:

for Self-Determination (LVV) left the assembly session.

21 CONSTITUTION OF THE REPUBLIC OF KOSOVO. Article 86, defines that the procedure of electing the president by parliament (assembly) is carried out in three rounds. In the first and second round, the President is appointed if they receive $2 / 3$ of the votes of the total number of deputies, from all 120 deputies of the Parliament of the Republic of Kosovo. The President of Kosovo is appointed in the third round if they receive the majority of votes of all deputies of the Assembly of the Republic of Kosovo (at least 61 votes).

22 MINUTES of the meeting of the Assembly (note 18).

23 Decision of the Assembly of Kosovo for electing the president of the Republic of Kosovo, No. 04-V-04, dated 22.02.2011.

24 MINUTES of the meeting of the Assembly (note 18).

25 CONSTITUTION OF THE REPUBLIC OF KOSOVO. Article 87 defines that the mandate of the elected president starts at the moment of taking the oath. 2008.

26 DECISION of the Assembly of Kosovo (note 23). 
The President of the Republic of Kosovo shall be elected by a two thirds (2/3) majority of all deputies of the Assembly. [...] If a two thirds (2/3) majority is not reached by any candidate in the first two ballots, a third ballot takes place between the two candidates who received the highest number of votes in the second ballot, and the candidate who receives the majority of all deputies of the Assembly shall be elected as President of the Republic of Kosovo.

The request of the applicants proceeded to the Constitutional Court on the basis of Art. 113.5, which assigns the Constitutional Court to review the constitutionality of decisions issued by the Assembly, for which, ratione personae, at least 10 MPs have issued a claim within eight days of the adoption of said decision. Art. 113.5 allows for the petition of the MPs - from a ratione materie perspective - to question both the material and the procedural compliance of the decision with the Constitution ${ }^{27}$. This is further supported by Art. 42 of the Law on the Constitutional Court and Art. 56 (1) of the Rules of Procedure of the Constitutional Court of $\mathrm{Kosovo}^{28}$. The case easily passed the admissibility test, demonstrating the court's commitment to actively engage in the review of the matter $^{29}$.

\subsection{Applicant's position in Hamiti et al}

The applicants raised several disputes in regard to the criteria under Art. 86 which were allegedly violated during the appointment procedure in the Assembly. The key arguments are summarized below.

First and foremost, the applicants claimed that the appointment procedure used by the Assembly to appoint the President violated the constitutional provisions relating to quorum. Art. 69 (3) establishes that the Assembly has a quorum when at least one more than the half of its members are present in the session. The general rule is that a $50 \%+1$ of MPs are required for a parliamentary vote. However, the applicants contended that Art. 86 is a lex specialis rule which requires a special quorum for the parliamentary appointment of the President of the Republic. They argued that the parliament needs a special, (at least) twothirds quorum to appoint a president, because Art. 86 requires that the president be elected by a two-thirds majority of all MPs, respectively 80 MPs. During the appointment of Mr. Pacolli, only 67 MPs were present, 13 less than needed to

27 CONSTITUTION (note 11), Article 113.5.

28 LAW NO. 03 / L-121 on the Constitutional Court of the Republic of Kosovo, dated December 16, 2008, Article 42 and Rules of Procedure of the Constitutional Court, dated December 23, 2010, Rule 56.1 .

29 JUDGMENT of the Constitutional Court, in the case KO29/11, (note 7), paragraphs 62-67.; See also: THE ORDER of the Constitutional Court, no. KSH. 29/11. The reviewing panel that would have assessed the admissibility of the case was composed of three judges: Snezhana Botusharova (Presiding), Enver Hasani and Ivan Cukalovic. 
meet a two-thirds quorum ${ }^{30}$. Applicants therefore did not contest the general rule on quorum ${ }^{31}$ but rather the lack of a specialized, minimum quorum needed for the appointment of the president ${ }^{32}$. Applicants did not however state the interpretative ground upon which a specialized rule on quorum is built. Rather, the applicant claimed that as long as there was no two-thirds quorum, none of the sessions should have been able to proceed (given the requirement that at least two-thirds of MPs must vote in favour of a presidential appointee $)^{33}$. This invokes a violation of Art. 86 (4), according to the applicants.

Secondly, the applicants contended that the fact that only one candidate had been nominated for the position, as a result it makes the appointment unconstitutional. This claim was grounded in Art. $86.6^{34}$ of the constitution which reads: "if a two-thirds (2/3) majority is not reached by any candidate in the first two ballots, a third ballot takes place between the two candidates who received the highest number of votes in the second ballot, and the candidate who receives the majority of all deputies of the Assembly shall be elected as President of the Republic of Kosovo"35. The applicants insist on a strict literal reading of the above provision, giving relevance to the word 'none', which, in their view, should be aiming to the idea of pushing for competition in the pool of at least two applicants. Insistence on the literal meaning of the provision builds upon a strategy opposite to that used in the applicants' first line of argumentation which builds upon the intended and inherent requirements for quorum. This second claim of the applicants, nevertheless, points to the need for a competitive appointment process. President Pacolli replied to the applicants, stating his position that the quorum for appointing the president was not a 'special situation' and that the general rule on quorum applies ${ }^{36}$.

\subsection{Merits of the decision in Hamiti et al}

The court deferred quite substantively to the position of the applicants. It analysed the case on two premises: first, whether Art. 86 includes any criteria relating to the number of candidates that need to compete for the post in order

30 JUDGMENT of the Constitutional Court, in the case KO29/11, (note 7), paragraphs 23-31.

31 RULES of Procedure of the Assembly of Kosovo, Article 51, defines that in order to carry out a session of the Assembly of the Republic of Kosovo, a majority of the deputies of the Assembly or a minimum of 61 deputies must be present.

32 They reiterate that the number of deputies present at the session of the assembly on February 22 was 67, whereas the minimum number needed to elect the president of Kosovo is 80 deputies.

33 JUDGMENT of the Constitutional Court, in the case KO29/11, (note 7), paragraphs $23-31$.

34 Ibid, (note 7), paragraphs 32-34.

35 CONSTITUTION (note 11), Article 86.5.

36 The response of the President of Kosovo Mr. Behgjet Pacolli, with regard to the request of the Applicants, dated March 10, 2011. 
for the procedure to be valid and second, whether a special rule on the quorum needed for appointment is inherently codified in the reading of Art. 86 of the Constitution.

3.3.1 Whether there is a rule on the number of candidates as a procedural requisite

The Constitutional Court considered the issue of the number of candidates participating in the appointment procedure as relevant and well within the scope of Art. 86. The court drew upon the literal meaning of Art. 86 (5) and Art. 86 (6). It argued that both provisions refer to the number of persons competing for the post of president, as follows: '[...] if none of the candidates receives the majority of $(2 / 3)$ in the first 2 ballots [... ${ }^{37}$. The court noted that Art. $86(6)$ is even more explicitly as it reads: 'If none of the candidates is elected as President of the Republic of Kosovo in the third ballot, the Assembly shall dissolve and new elections shall take place within forty five (45) days $[\ldots]^{33}$. Aligning with the literal meaning of both provisions, the court argued that the pronoun 'none' reflects the obligation to ensure that there is more than one candidate for President. The Court justified its ruling, arguing that if the term 'none' had no significant meaning in this context, then the procedure that leads to new elections would never appear in practice. While the Court's decision reflects a result-oriented interpretation, the court did not justify what the process should look like if there is no second interested candidate but a two-thirds majority of MPs support the sole applicant. The insistence on this standard creates space for greater political competition and plurality but could potentially make reaching consensus more challenging.

Because Mr. Pacolli was the only candidate competing for the position of president, ${ }^{39}$ the court concluded that the Assembly violated the requirements of Art. 86 (5), clearly deferring to the applicants' position on this issue.

\subsubsection{The rule on special quorum in the procedure for appointing the president of republic}

The Court argued that, the rule requiring two-thirds majority approval is at the same time a rule on quorum ${ }^{40}$. The court argues that a special rule on quorum applies in this case, because, it would be unfounded and illogical to allow a session to occur if the bar for participation is lower than the number of votes needed to pass an appointment. The majority's judgment further contains that,

37 CONSTITUTION (note 11), Article 86.5.

38 See again: JUDGMENT of the Constitutional Court, in the case KO29/11, (note 7), paragraphs 68-69.

39 PACOLLI, Behgjet had obtained 64 signatures of deputies, in line with Article 86.2 of the Constitution of the Republic of Kosovo (note 11).

40 JUDGMENT of the Constitutional Court, in the case KO29/11, (note 7), paragraph 78. 
"the election of the President of Kosovo, who pursuant to Article 83 [Status of the President] is the Head of State and represents the unity of the people of the Republic of Kosovo, is of such importance, that all deputies, as the representatives of the people of Kosovo, should consider it their constitutional duty, unless excused by the President of the Assembly, to participate in the procedure for the election of the President as laid down in Article 86 [Election of the President] of the Constitution" 41 .

As such, the court determined that the quorum needed for appointing the President is two-thirds of all MPs, or $80 \mathrm{MPs}^{4243}$. Moreover, the Court ruled that this quorum is required in all three rounds of voting for the appointment of the President, despite the fact that Art. 86 makes it possible to appoint the President with only 61 votes in the last round. The Court's interpretation is slightly contradictory in this regard, because the Court first justified the need for a special quorum in this case citing the fact that a quorum of two-thirds of MPs was inherently necessary as the first two rounds could otherwise not result in the appointment of a president with support from two-thirds of MPs; at least the number of MPs required to appoint the president would need to be present in the session. The same logic requiring a two-thirds quorum in the first two rounds would not hold for the third round within which only 61 votes are needed for the successful appointment of the president. However, the ruling of the court in Hamiti stipulated that none of the rounds could be commenced if the two-thirds quorum was not met. To that end, the court made it obligatory for every MP to participate in the session for appointing the president of republic, preventing opposition groups from boycotting an appointment session as a means of democratic protest or expression. The court justified this, arguing that a President is expected to represent the unity of the people rather than the fight between political parties in the parliament. Additionally, the court insisted that the three rounds for appointing the president should take place consecutively. In the Court's view, separating the rounds would give parties opportunities in between rounds to pressure MPs to vote for a certain candidate ${ }^{44}$.

As a result, the Court overturned the decision of the Assembly to appoint Mr. Pacolli as President of the Republic as the Assembly did not comply with Art. 86 of the Constitution.

Two judges offered the dissenting opinion with regard to the rule on quorum, arguing that the quorum requirements established by the Court allowed a minority of barely 41 deputies to block the procedures, thus preventing the

41 QERIMI, Qerim \& QORROLLI, Vigan. A Constitutional Tradition in the Making: The Presidents' Cases and the Role of Kosovo's Constitutional Court in the Process of Democratic Consolidation. ICL Journal | vol 7 (1/2013), pp.64.

42 JUDGMENT of the Constitutional Court, in the case KO29/11, (note 7), paragraph 85.

43 CONSTITUION (note 11), Article 86.4.

44 JUDGMENT of the Constitutional Court, in the case KO29/11, (note 7), paragraph 89. 
Assembly from appointing a President. Furthermore, they also considered that such a rule would also render moot Paragraph 4 of Article 86, since the Assembly would then be unable to appoint the President by a simple majority. In their opinion, that solution went against the drafters of the Constitution, whose intention was to prevent such manoeuvres from a minority ${ }^{45}$.

"Voting by the members of legislative body is part of the business of that legislative body. The rules applicable to each can be, and often are, different. Pursuant to Paragraph 3 of Article 69 of the Constitution, the Assembly of Kosovo has its quorum when more than one half (1/2) of all Assembly deputies are present. That provision is the only one mentioning a quorum. The Rules of Procedure of the Assembly also establish the same quorum for the Assembly, which is more than one-half of all deputies (61 deputies). That quorum is kept unchanged during the session, regardless of the business of the Assembly even though the minimum number of votes to take a decision may change. A rule that would require a quorum of $2 / 3$ would allow a small minority of the members (41 deputies) to prevent the majority of parliamentarians from doing the business and will of the majority by simply refusing to meet and do the work they took an oath of office to do. It would prevent the majority from discharging the duties they were duly elected to do. It would prevent the majority from discharging the duties they were duly elected to do. It effectively would allow the minority to thwart the democratic will of the majority. It would also prevent the Assembly from acting pursuant to Paragraph 4 of Article 86 of the Constitution and elect a President on a simple majority vote of the deputies of the Assembly. Such an interpretation would make Paragraph 4 of Article 86 meaningless. The drafters of the Constitution specifically designed the Constitution in such a way so as to prevent the minority from thwarting the will of the majority"46.

They further argued that the ruling inevitable led to new elections, since the Court lacked the authority to either demand a re-vote from the Assembly or to offer another alternative.

"Constitution in the election procedure of the Assembly, the Constitution then mandates that the Assembly shall dissolve and new national elections of the Assembly shall take place within forty five days. By declaring that the election process on 22 February 2011 violated the Constitution, this Court declared that the Assembly had not elected a President after the third round of balloting. The Constitution then mandates the dissolution of the Assembly and new national elections within 45 days.

45 CASE No. KO 29/11, Dissenting Opinion of Judges Robert Carolan and Almiro Rodrigues, Ref. No.: OM 108/11, Pristina, 30 March 201, page,.3. [Online]. Available at: http://www. gjk-ks.org/repository/docs/gjk_ko_29_11_om_ang.pdf. Accessed: 25.03.2017.

46 Ibid, (note 45), page 3. 
The Court's erroneous decision of today, which cannot be without consequences, forces that result. The Court by simply declaring the election process on 22 February 2011 violated the Constitution implicitly acknowledges that it does not have the authority to order the Assembly to re-vote. Since the Court also does not have the power to declare the election unconstitutional without a remedy, the decision of the Majority forces the dissolution of the Assembly and new national elections' ${ }^{347}$.

\subsubsection{Constitutional impact of Hamiti et al}

The decision resulting from Hamiti et al had serious political ramifications. One of the most important political effects of the decision was that the country entered a second period of political stalemate. However, from a constitutional perspective, there are at least three constitutional standards that derived from the Court's decision. First, the decision prompted several political downturns in practice. It pushed the coalition government to seek to reach a relatively consensual, political decision for appointing the next President. The \position\ of the President was handed over to the Speaker of the Assembly as acting President. Footnote The push for a new president who could receive greater support in parliament was seen as a prerequisite for organizing the appointment session of the Assembly, which, otherwise, would not have quorum due to the boycott of opposition political parties, or, if unsuccessful, would result in parliament's dissolution and trigger new elections. As such, the governing coalition and the biggest opposition political party at that time, LDK, reached a consensual agreement to appoint Ms. Atifete Jahjaga as the new president of republic ${ }^{4849}$. This represented a change from a system wherein the governing coalition most influential in the appointment of a new president to one wherein the opposition parties had substantial influence. Ms. Jahjaga was appointed in line with the two standards resulting from Hamiti et al, as Ms. Noverberdaliu was also a formal candidate and 100 MPs participated in the session for her appointment. Ms. Jahjaga received 80 votes in the first round, more than the two-thirds majority needed for her appointment. Ms. Noverberdaliu received only 10 votes, suggesting that the contest may have been contrived for the purpose of meeting the formal requirement of a competitive appointment process. In the same session, the Assembly also passed a resolution establishing an ad hoc commission for amending the Constitution of the Republic of Kosovo, so that future presidents

47 CASE No. KO 29/11, Dissenting Opinion of Judges (note 45), page 5.

48 The signed agreement by the three leaders of political parties, Hashim Thaçi (PDK), Isa Mustafa (LDK) and Behgjet Pacolli (AKR), dated April 6, 2011.

49 MINUTES of the session of the Assembly of Kosovo no.P-08, dated April 7, 2011. 
would be elected by popular vote ${ }^{505152}$. This never came to fruition and may have been a political tactic, as none of the core parties ever seriously supported that idea later on.

Secondly, and most importantly, the decision seems to have legitimized the opposition's use of a session boycott as a tool to prevent the governing coalition from passing to round three, wherein the appointment of a president could pass with a simple majority of $50 \%+1$. This tool enhanced the role of the opposition in the appointment process, making it unlikely that a candidate without some opposition support could be successfully appointed as President. Even if a governing coalition maintained a two-thirds majority, the dissent of a few coalition MPs would again make the governing coalition reliant on opposition support. Therefore, with the Court's decision, it became quite unlikely that the president of republic could be appointed without the support of members of the opposition.

\section{Here it goes again: The decision of the court in Derguti et al}

Although Hamiti et al seemed to result in a firm decision with regard to the standards surrounding the procedure for appointing a new President, similar issues arose five years later after the appointment of Mr. Hashim Thaqi as the new President of Kosovo. The opposition parties again contested the appointment's compliance with the constitution ${ }^{53}$. Mr. Thaqi's appointment resulted from an agreement of the coalition government - a coalition that controlled 89 MPs, more than the two-third majority required. However, Mr. Thaqi had been the head of a political party and the opposition legitimately questioned his capacity to act as the 'representative of the unity of the people.' Due to the opposition's dissent during and criticism of the session which resulted in the appointment of Mr. Thaqi, ${ }^{54}$ the opposition contested that a President appointed under such conditions could not be considered a proper representative of the unity of the people. During the appointment process, the opposition MPs used several violent methods to prevent the session from proceeding normally (including the use of tear gas in parliament which resulted in police presence), the parliament took several (three consecutive) breaks, and the Presidency of the assembly excluded the large majority of opposition MPs from the plenary session ${ }^{55}$.

50 RESOLUTION of the Parliament of the Republic of Kosovo, no. 04-R-2, dated April 7, 2011.

51 DECISION of the Assembly of the Republic of Kosovo, no. 04-V-12, for establishing the Committee for amending the Constitution of the Republic of Kosovo.

52 MINUTES of the session of the Assembly of Kosovo, P-013, dated April 22, 2011.

53 MINUTES of the extraordinary session of the Assembly of Kosovo no. P-55, dated February 26 2016. [Online]. Available at: http://www.kuvendikosoves.org/common/docs/proc/ proc_2016_02_26_11_6334_al.pdf. Accessed: 20.03.2017.

54 MINUTES of the extraordinary session of the Assembly of Kosovo (note 53).

55 Ibid, (note 53). 
After three consecutive breaks and with the large majority of opposition MPs excluded from the session on basis of a disciplinary decision, the Presidency and the Speaker of the Assembly decided to proceed with the appointment process. The two standards resulting from Hamiti et al were formally met: there were two candidates running for the position, and there were 81 MPs (primarily members of the governing coalition) present during all the three rounds of voting. Mr. Thaqi was officially appointed as President after the third round of voting, having received 75 votes $^{56}$.

\subsection{The position of the applicants in Derguti et al}

The applicant's claim that the appointment of President Thaqi violated the Constitution was based on two main points. First, the applicants argued that the ruling resulting from Hamiti et al requires all 120 MPs of the assembly to cast their ballot during all three rounds of voting ${ }^{57}$. They also argued that for the President to represent the unity of the people, and based on the court's previous line of reasoning, all MPs are obliged to vote - should they refuse, the session should be suspended. Secondly, the applicants argued that because the opposition MPs were excluded from the session, with some of them detained and forcibly barred from participating, the session violated the constitution which calls for a procedure for the appointment of the president which reflects a level of consensus needed to ensure that the appointee represents the unity of the peo$\mathrm{ple}^{58}$. The applicants basically argued that for the president to truly represent the unity of the people, he should not be contested politically to such a level that his legitimacy is seriously called into question.4. 2 Merits and impact of the decision in Derguti et al.

The court ruled the case as inadmissible on the ground of it being unfound$\mathrm{ed}^{59}$. Nonetheless, the Court still issued statements on some substantive aspects of the case, demonstrating the court's interest in reviewing/clarifying the standards established as a result of Hamiti et al. First, the Court addressed the legitimacy component, considering whether applicants for president must demonstrate that they are objectively capable of representing the unity of the people. Second, the Court reconsidered and clarified the ruling on quorum vis-a-vis minimum thresholds and its application in the third round of voting.

In regard to the second issue, the court again ruled in line with the standards set out in Hamiti by concluding that a two-thirds quorum is needed to match

56 Ibid (note 53). President of the Republic of Kosovo in the session of the Assembly of the Republic of Kosovo was elected Mr. Hashim Thaçi with 75 votes of deputies.

57 RESOLUTION in Inadmissibility of the Constitutional Court of Kosovo In Case No. K047/16 (note 8) paragraph 31.

58 RESOLUTION in Inadmissibility of the Constitutional Court of Kosovo In Case No. K047/16 (note 8), paragraph 33.

59 Ibid, (note 8), paragraphs 75-76. 
the rule requiring a two-thirds majority vote of approval. ${ }^{60}$ With regard to the applicants' interpretation of paragraph 85 of the Judgment in Hamiti et al which had stated 'that all 120 deputies should vote' in the procedure of appointment of the president, ${ }^{61}$ the Court specified that "it is neither a constitutional prerequisite nor a requirement for the validity of the decision for the election of the President of the Republic of Kosovo under Article 86, paragraphs 4 and 5 that all hundred and twenty (120) Deputies be present and voting, as stipulated by the Applicants' Referral"62.

Though issuing no change of interpretation with regard to the standards for quorum in the first and second rounds of voting, the Court revisited the issue of quorum with regard to the third round. The court came to the conclusion that in the third round of voting the quorum is $61 \mathrm{MPs}$ (the majority of all MPs), mirroring the number of votes required to approve a candidate in the third round. The court therefore fundamentally departed from the standard set forth in Hamiti et al, which called for a quorum of two-thirds of MPs in all rounds of voting (but left the option to participate with each individual MP) ${ }^{63}$. This new ruling limits the role and influence of the opposition in the third round of voting. The court further weakened the standard with regard to the criterion used for assessing quorum. While in Hamiti et al the court advised that a yes or no vote (meaning a valid vote) must be cast by an MP in order for that MP to count towards quorum, in Derguti the court made this rule far more flexible allowing an MP to count towards quorum as long as his vote is cast in the ballot box (independent of whether the vote is valid or not).

Second, the court dismissed as unfounded all legitimacy-based arguments. It clearly makes the scope of the President's role as representative of the unity of the people disconnected to the external legitimacy which a representative of the unity of the people should normally have.

\section{The systemic impact of constitutional standards in the appointment of the president of republic in Hamiti et al and Derguti et al}

A logical point of preliminary conclusion would be to deduce that the procedure for appointing the President impacts the role that he plays in the political system. Based on Art. 86 which provides for the President appointed by parliament as opposed to elected directly by the people $e^{64}$. Based on Kosovo Constitution the Presidential role is limited. However, the president's role in exercis-

60 Ibid, (note 8), paragraph 62.

61 Ibid, (note 8) paragraph 67.

62 Ibid, (note 8), paragraph 74.

63 Ibid, (note 8) 63 and 64.

64 For a comparison of the president's role in both systems, see: NOVÁK, Martin. Major differences between the presidential and parliamentary republics. Metropolitan University Prague, 2014, pp.3. 
ing his constitutional functions remains dependent on, among other things, the nature of the political methods used to appoint the president. Because the Constitution tasks the president with representing the unity of the people, the way he is perceived in the Assembly is of utmost political importance. Therefore, the appointment procedure plays an important role ${ }^{65}$. A directly elected president would normally enjoy more popular legitimacy ${ }^{66}$ However the same would be if the rules pertaining to the parliamentary appointment of the President require a high level of consensus within parliament which can give a certain objective legitimacy to the presidency. Nevertheless, the two constitutional court decisions in Hamiti et al and Derguti et al play a key role attributing such legitimacy on the President's post by imposing a wider consensual while electing the President.

\section{Comparison cases when it comes to the election of the President that represents the unity of the people}

Unlike the case of the Republic of Kosovo, where the Constitutional Court through cases Hamiti and Derguti, has created quorum standards and the number of candidates in the battle for President, Albania has acted in the opposite direction, by facilitating greatly the procedure of electing the President and the number of votes required for election of the president. Until 2008, the President of the Republic of Albania is elected by a qualified majority of three-fifth of all MPs. This majority was required during all five (5) rounds of voting. Following the constitutional crisis in Albania regarding election of the President in 2007, where the Albanian Parliament with great difficulty reached three-fifth of the votes for the election of the President, and so was reached only after the support of six MPs opposition ${ }^{67}$. After the crisis in the election of the President in 2007 and the lack of consensus on the election of the next President, the Albanian Parliament in 2008 decided to change the constitution to lower the required majority of votes to elect the President ${ }^{68}$. After the constitutional changes in 2008, the President of the Republic of Albania is elected in one of five (5) rounds of voting, but only the first three rounds require a qualified majority of three-fifth for the election of the President. However, in the fourth and fifth rounds, the President can be elected by a majority vote of the Parliament ${ }^{69}$. The case of Albania is contrary if compared with the case of Kosovo, because in Albania the parliament revised the constitution to reflect the need to surpass crisis triggered due to lack

65 E.g.: ELGIE, Robert. The President of Ireland in comparative perspective" Irish Political Studies. 2005, pp.503.

66 JANDA, Kenneth. Presidential election in Russia and the United States: Is majority Popular Vote Desirable. Conference on political Analysis, Moscow, 1999, pp.3.

67 Presidential Election in Albania, 20th June 2007, [Online]. Available at:http://www.robertschuman.eu/en/eem/0651-presidential-election-in-albania-20th-june-2007. Accessed: 29.03.2017.

68 AMENDING LAW NO: 9904 of the Constitution of the Republic of Albania, date 21.4.2008, article 5.

69 Ibid, article 5. 
of consensus whereas in Kosovo the court followed an opposite direction; obliging the parliament to reach consensus for the appointment of the president. In Albania, after the constitutional amendments the President can be elected without political consensus but only with the votes of a governing coalition.

In addition, similar cases have been handled differently. For instance, the Moldovan Constitutional Court followed a different line of argumentation when reviewing a similar situation. It argued that the failure of the Parliament to manage to consensually elect a candidate for the President 'has generated a rupture of this constitutional unity as it fails to secure the normal functioning of the Presidential institute ${ }^{70}$. In Kazakhstan, despite the fact that it is a presidential system, the President of the Republic is responsible for acting as a "symbol and guarantor of the unity of the people and the state power" and for "ensuring responsibility of the state institutions before the people". However, the personal authority of the President also plays an important role in the exercise of his constitutional authority ${ }^{71}$. Also in the presidential elections in Austria in 2016, the election of the President ended in the Constitutional Court due to irregularities listed in this election. As a result, the Austrian Constitutional Court ruled that one of the reasons for the cancellation of these elections was that the votes cast by postal ballot were estimated illegally ${ }^{72}$. Although the Austrian president unlike that of Kosovo is directly elected by the people, this case shows the importance of voting in the presidential election procedure.

\section{Conclusion}

On the one hand, the standards on quorum deriving from the two decisions play an important role in ensuring the appointment of the President who can act as a 'representative of the unity of the people. The rule on quorum requires the presence of two-thirds of MPs during the first two rounds of voting. The Derguti case removed this requirement for the third round. Because Kosovo is a parliamentary democracy, it is rare for broad coalitions including at least two-thirds of MPs to come together to establish a coalition government. In Kosovo's recent history, this happened only once in 2014. As such, because the rule on quorum requires a candidate to receive two-thirds approval within the first two rounds, it would be very difficult to appoint the President without the participation of and at least minimal support from the opposition. Even if the coalition government

70 CONSTITUTIONAL COURT Republic of Moldova. JUDGMENT ON CONSTITUTIONAL REVIEW of certain provisions of the Law no. 1115-XIV of 5 July 2000 amending the Constitution of the Republic of Moldova (modality of electing the President) (Complaint no. 48b/2015), paragraph 192.

71 KEMBAYEV, Zhenis. The Rise of Presidentialism in Post-Soviet Central Asia: The Example of Kazakhstan. KIMEP University, 2011, pp.438, (referring to the 1995 Khazak constitution, Art, 40 (2)).

72 CONSTITUTIONAL COURT Austria. Case W I 6/2016-125. pp.171-172 (IV Result, paragraph 1), 1 July 2016, Freyung 8, A-1010 Vienna. [Online]. Available at: https://www.vfgh. gv.at/downloads/VfGH_W-I-1-2016_EN.pdf. Accessed:30.03.2017. 
was broad enough to include two-thirds of MPs - as is the case with the current PDK-LDK coalition - a small group of opposition within the governing coalition could ruin a coalition deal for the appointment of a president. Both Hamiti and Derguti imply that the appointment of the President should result from an extensive consensus between at least two-thirds of the members of Parliament. This formula, from a political perspective, gives the opposition notable influence and strength in the case that they would boycott or seek to prevent the appointment of the Presidential candidate put forward by the governing coalition. Without a broader consensus which includes at least some members of the opposition, a presidential appointment would likely be blocked by members of the opposition. The President may then also feel politically obliged to respect the consensual deal that made the appointment possible, resulting in a more neutral and moderate rather than strictly partisan president. In doing so, the Court basically argues in the lines of a representative President, as opposed to the constitutional role that is usually granted to the figure of a President in a purely presidential system.

On the other hand, by ruling that an appointment session cannot proceed without there being sufficient quorum during the first and second rounds, the Court avoids the application of Art. 86 (7) which requires new elections to be held in the case that parliament is unable to appoint the President in three rounds of voting. This serves as a strong safeguard for the governing coalition, who does not want to risk losing seats in parliament due to an election brought about by an opposition boycott. This also limits possibilities for the opposition parties to bring about new elections by boycotting the sessions for the appointment of the president.

The Court's decision in Derguti et al makes it clear that the role of the President as a representative of the unity of the people to be necessarily linked to external legitimacy. This bars person from formally or legally calling into question the President's capacity to act as a representative of the unity of the people on the grounds of the President's behaviour or perceived legitimacy. The Court at least would have no jurisdiction in such a case, as ratione materiae the court insists that the president's role as representative of the unity of the people is not constitutionally linked to the president's behaviour or perceived legitimacy. In the view of the court in Derguti, any argument citing the political behaviour of the President after his appoint does not fall within the scope of constitutional rules relating to the President's role as representative of the unity of the people. One must note that, often, the debate over the President's role as representative of the unity of the people is related with his competences, this is to be an example of a semi-presidential system as opposed to a parliamentary republic. However, this is not the case in Kosovo, where the standards resulting from Hamiti and Derguti focus more on the president's role as a representative of the unity of the people as a function of the procedural conditions upon which his appointment is based rather than of the relevance of his constitutional competences. 
This article concludes that the two decisions of the Constitutional Court in Hamiti et al and Derguti et al have significant constitutional impact on the Republic of Kosovo's political and constitutional system. They both demonstrate the Court's willingness to actively engage with a positive-legislating attitude and issue rulings on the constitutional rules relating to the appointment of the President and the President's role as the representative of the unity of the people. The two decisions also reflect that the appointment of a head of state in a parliamentary republic should result from a process of coalition government formation and should draw upon consensual, multi-party support. To this end, Hamiti et al and Derguti et al cases make the procedure for the appointment of the President more inclusive and less vulnerable to being dominated by the coalition government. The rule on quorum makes oppositional boycott an effective tool for preventing the coalition government from unilaterally appointing the president. The article argues that the court's decisions were built upon constitutional principle, rather than on a literal reading of Art. 86 (although still sidelining issues relating to external legitimacy of the president as beyond the scope of constitutional regulation ratione materiae).

\section{References (alphabetical order)}

CORRIAS, Luigi. The Passivity of Law - Competence and Constitution in the European Court of Justice. London, Springer, 2011

COUTINHO, Luis, Pereira, LA TORRE, SMITH, D. Steven. Judicial Activism - An Interdisciplinary Approach to the American and European Experience. Ius Gentium: Comparative Perspectives on Law and Justice 44, Springer International Publishing, Switzerland, 2014

DEMOCRATIC INSTITUTE OF KOSOVO. Election of President by People: Necessity of time or common rhetoric. July, 2015

ELGIE, Robert. The President of Ireland in comparative perspective" Irish Political Studies. 2005;

JANDA,Kenneth. Presidential election in Russia and the United States: Is majority Popular Vote Desirable, Conference on political Analysis, Moscow, 1999

Judge TUNHEIM, John. Rule of Law and the Kosovo Constitution. Minnesota Journal Of Int'l Law, vol. 18:2, 2009

KEMBAYEV, Zhenis. The Rise of Presidentialism in Post-Soviet Central Asia: The Example of Kazakhstan. KIMEP University, 2011

MARCO, Joseph. The New Kosovo Constitution in a Regional Comparative Perspective. Review of Central and East European Law 33, 2008

MORINA,Visar. The Legislative Veto from the perspective of the Kosovo Constitution. Denning Law Journal, vol 26, 2014

NOVÁK, Martin. Major differences between the presidential and parliamentary republics. Metropolitan University Prague, 2014

QERIMI, Qerim \& QORROLLI, Vigan. A Constitutional Tradition in the Making: The Presidents' Cases and the Role of Kosovo's Constitutional Court in the Process of Democratic Consolidation. ICL Journal | vol 7 (1/2013) 